\title{
16
}

\section{Dealings in native title and statutory Aboriginal land rights lands in Australia: What land tenure reform is needed?}

Ed Wensing

\section{Introduction}

The current debate about Indigenous land tenure reform is skewed toward a neoliberal market view of private home ownership and capital accumulation at the expense of communal forms of tenure. I come at these issues from a very different perspective and background. As a land use planner, land administration and land tenure have been an integral part of my professional life since the early 1970s.

In 2011, I was lead researcher in a study undertaken for the Western Australian Department of Indigenous Affairs on whether the Aboriginal Lands Trust estate in Western Australia could be transferred to Aboriginal people within the existing land tenure system (SGS Economics and Planning 2012). The study found that there was:

- a low level of understanding among Aboriginal people of what 'home ownership' means and the implications of becoming a home owner;

- a high level of misunderstanding among Aboriginal people of the Crown's land tenure system and misapprehension about the need for change; 
- a high level of mistrust among Aboriginal people and native title holders because governments are notorious for continually changing their policies and positions.

The study also found that native title holders are reluctant to surrender their native title rights and interests in exchange for a form of tenure of which they have little or no understanding and which they regard as inferior to customary land rights. But none of this is new to Aboriginal people.

With my professional land use planning and land administration background, two larger questions arose for me from this study:

- Why do native title holders have to surrender and agree to the permanent extinguishment of their customary rights and interests in order to participate in the modern economy?

- Why is it not possible for customary rights and interests to be accommodated in conventional land tenure systems in a way that would enable the customary rights holders to engage in the modern economy on their lands, on their terms and without having to surrender and extinguish their native title rights and interests forever?

These two questions made me think more deeply about what Aboriginal land tenure reform is needed and they are the focus of my PhD research. ${ }^{1}$ This chapter provides some preliminary insights and arguments.

My starting position is that the current basis for admitting Aboriginal land rights into the Anglo-Australian framework of land law and tenure continues the dispossession of colonialism, only this time under the guise of inalienability and extinguishment. Under the new native title regime, the Crown has a monopoly power to extinguish customary rights and interests. Many statutory Aboriginal land rights regimes in Australia also severely restrict dealings in land held in Aboriginal ownership. I postulate that it is time to puncture some legal orthodoxies relating to property and dealings in land.

1 The focus of this paper is on mainland Australia. Consequently, the term Aboriginal is used except where the context makes it necessary to refer to Aboriginal and Torres Strait Islander people or Indigenous peoples. 


\section{A wider context}

Issues of land tenure reform must be viewed in a much wider context and Jon Altman (2014) has done this by looking at what he calls the Indigenous land titling 'revolution'.

Fig. 16.1 shows the extent of dispossession and re-titling of Aboriginal and Torres Strait Islander people's interests in land from 1788 to the present. As Altman (2014: 3) notes:

In 1788 Indigenous nations possessed the entire continent. Then during a prolonged period of land grab from 1788 to the late 1960s Indigenous peoples were dispossessed. But then, from the late 1960s, there has been an extraordinary period of rapid legal repossession and restitution that is ongoing. This has not occurred as part of some coherent policy framework, but rather as a somewhat ad hoc land titling 'revolution' driven intermittently by political, social justice and judicial imperatives.
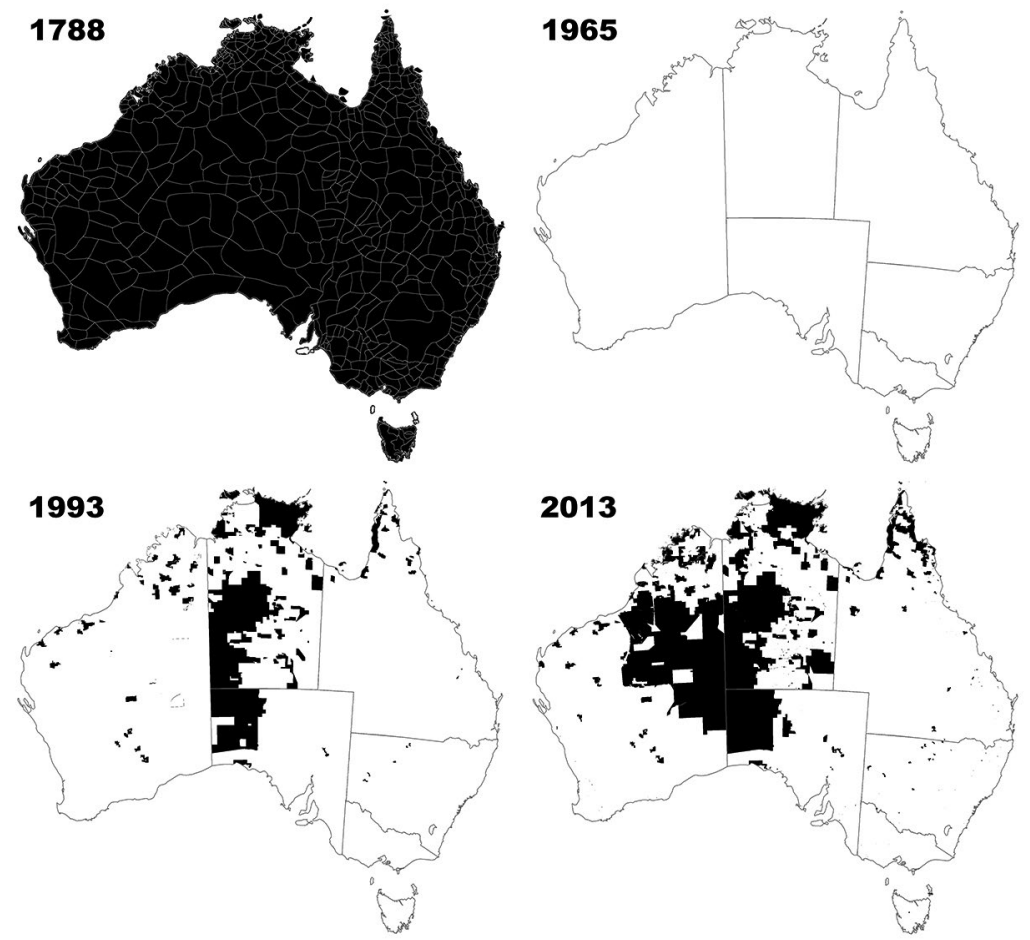

Fig. 16.1 A snapshot of Indigenous-held land from 1788 to 2013

Source: Altman (2014) 
The land titling revolution includes a range of land rights grants, purchases, native title determinations and areas subject to Indigenous land use agreements or other joint management arrangements. Altman has recently mapped these land titles (Altman 2012, 2014) and they total around 2.5 million $\mathrm{km}^{2}$ or roughly 33 per cent of terrestrial Australia (Fig. 16.2). ${ }^{2}$ This includes land held under general land legislation that allows governments to create reserves, freehold title or leases for the benefit of Aboriginal or Torres Strait Islander people. It also covers statutory land rights regimes which generally grant an inalienable freehold title to traditional owners (who are identified in accordance with traditional laws and customs and are communal land holders) or to Aboriginal or Torres Strait Islander residents of a discrete community. Finally, it includes land held under the Native Title Act 1993 (Cwlth) (NTA) which provides for the recognition of the communal group or individual rights and interests of native title holders under their traditional laws and customs in relation to their land or waters.

Altman (2014: 7) also highlights that most Aboriginal and Torres Strait Islander Australians do not live on Aboriginal titled land (Fig. 16.3), estimating that less than 100,000 do so from a total Aboriginal and Torres Strait Islander population of 660,00 . He also notes that it is not clear how many living on Aboriginal lands are traditional owners (see Edelman 2009) or how many traditional owners live off their lands. By correlating population with land held under land rights or exclusive possession native title, Altman (2014: 7) estimates that over 80 per cent of the population in these locations is Aboriginal or Torres Strait Islander compared with a national proportion of just on 3 per cent. Altman also argues, hypothetically, that if all native title claims were successful, as much as 70 per cent of Australia could be under some form of Aboriginal title and as much as 40 per cent of the Aboriginal and Torres Strait Islander population could be resident on those lands.

2 Fig. 16.2 provides information on land titling under three tenures: land claimed or automatically scheduled under land rights law, an estimated 969,000 km²; 92 determinations of exclusive possession under native title law totalling $752,000 \mathrm{~km}^{2}$; and 142 determinations of non-exclusive possession under native title law totalling $825,000 \mathrm{~km}^{2}$. The last category often provides a weak form of property right that needs to be shared with other interests, most commonly commercial rangeland pastoralism. 
16. DEALINGS IN NATIVE TITLE AND STATUTORY ABORIGINAL LAND RIGHTS LANDS

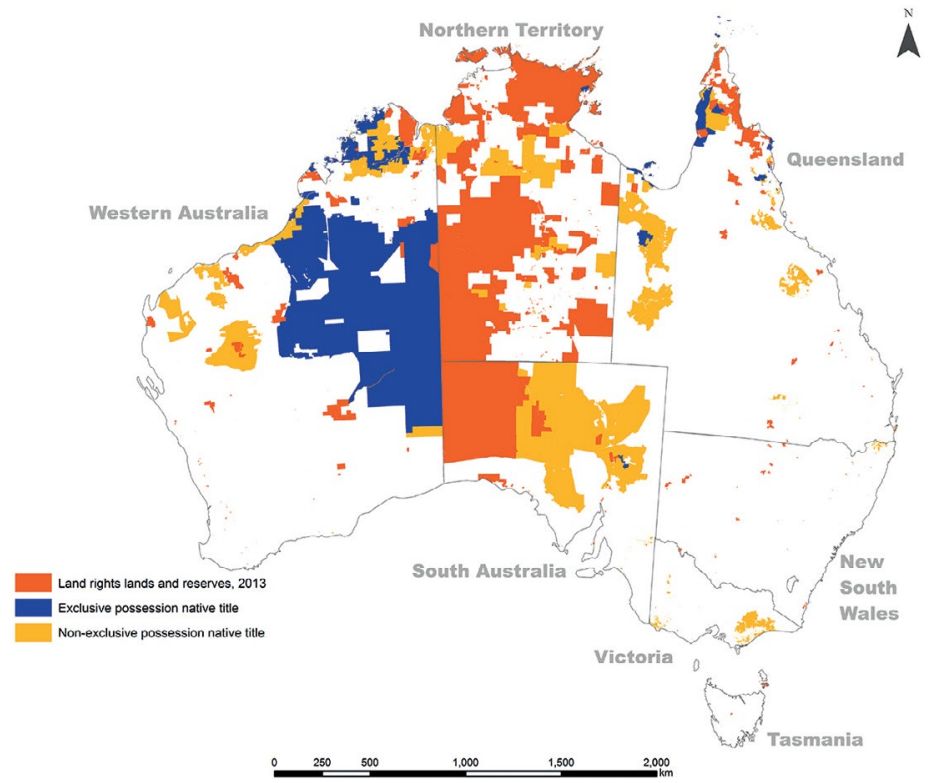

Fig. 16.2 Indigenous land titling under three tenures

Source: Altman (2014)

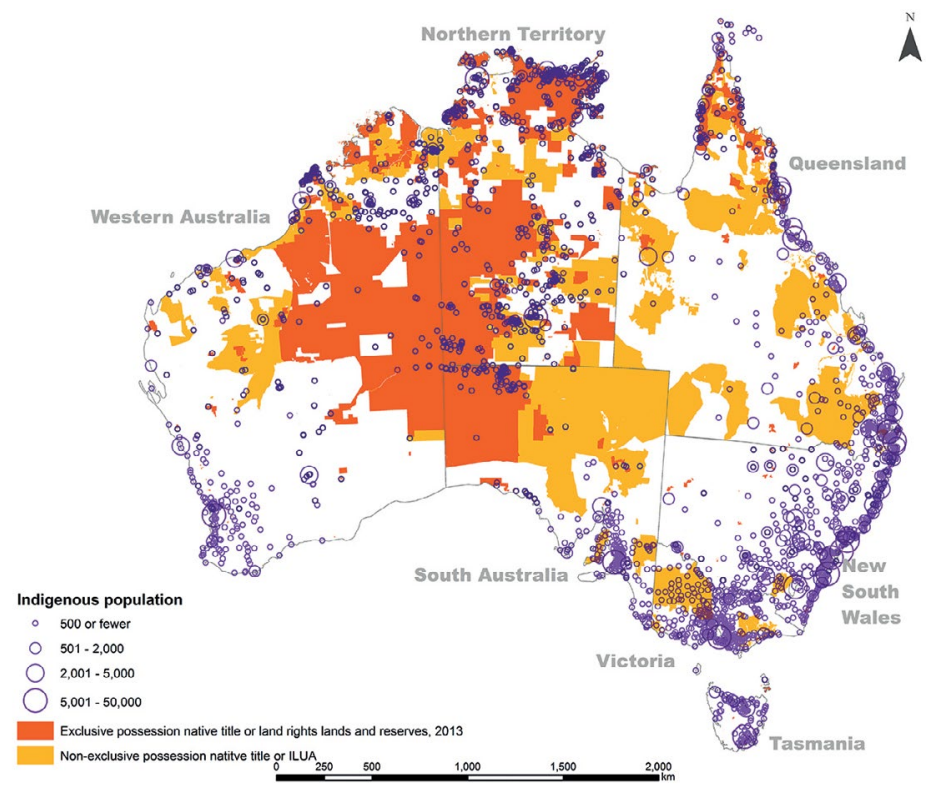

Fig. 16.3 Distribution of Indigenous population from the 2011 Census and Indigenous land titles in 2013

Source: Altman (2014) 


\section{Dealings in native title lands}

Land granted or reserved for the benefit of Aboriginal and Torres Strait Islander people under statutory land rights regimes does not extinguish native title rights and interests (Pareroultja $v$ Tickner 1993). Therefore dealings in Aboriginal communally owned land, or land reserved for the use and benefit of Aboriginal people, must also take into account the native title rights and interests for the dealings to be valid. ${ }^{3}$

Land subject to native title rights and interests is inalienable. Under the NTA, native title rights and interests can only be surrendered to the Crown. Further, a native title determination does not give native title holders any power or authority to grant subsidiary interests, including leases. Native title is also statutorily protected from debt recovery processes and is therefore unusable as security against a loan (Wensing \& Taylor 2012: 22; Wensing 2013).

The extent to which a prescribed body corporate $(\mathrm{PBC})$ or registered native title body corporate (RNTBC) is able to assign leases over land subject to native title rights and interests is also constrained by s. 56(5) of the NTA. This states that the native title rights and interests held by a body corporate are not able to be 'assigned, restrained, garnisheed, seized or sold' or 'made subject to any charge or interest ... as a result of the incurring, creation or enforcement of any debt or other liability of the body corporate', including 'any act done by the body corporate'. Section 56(5) is a reflection of what is regarded as the common law position on native title set out in $\mathrm{Mabo}$ (No. 2). It understands native title as a form of property subject to the Crown's radical title and therefore outside the real property system originating from the Crown. Native title cannot be transferred to anybody but the Crown. If that is the position, native title cannot subsist with the creation of a freehold title, lease or any sublease exercised pursuant to a lease (by native title holders or otherwise).

3 Dealing is the legal process through which land is bought and sold or otherwise transferred, also known as conveyancing. This involves the preparation of hard copy documents or records as evidence of a land transaction between parties. 
The NTA alters the common law by enacting the non-extinguishment principle and applying it to specified future acts. The reality is that in striking contrast to other citizens, native title holders cannot enter the market to realise the value of their property rights by leasing, mortgaging or selling them, because the Crown has a monopoly over the acquisition and extinguishment of those rights (Gover 2012). Nevertheless, Gover (2012) asserts that governments have a moral obligation, if not a fiduciary duty, 'to act "reasonably, honourably and in good faith" in dealings with Aboriginal and Torres Strait Islander peoples and to make "informed decisions" where their interests are at stake'. The complexity of dealings in native title land should not be underestimated, as discussed in more detail elsewhere (Wensing \& Taylor 2012: 22-7).

\section{Dealings in statutory Aboriginal and Torres Strait Islander land rights lands}

There are 23 different Aboriginal and Torres Strait Islander land rights statutes operating across Australia in addition to the NTA. The form of title under these statutory Aboriginal land rights regimes differs within and between jurisdictions, but titles are generally an estate in fee simple or freehold. These different statutory forms of title differ in whether the landholder can sell, lease, mortgage or dispose of their land. Table 16.1 is a comparative analysis of the statutory Aboriginal and Torres Strait Islander land rights regimes which lists the different statutes and includes details of the landowner, form of title, and whether private sale, leasing or subleasing, or mortgaging is permitted. ${ }^{4}$

4 The original source for this analysis was the Aboriginal and Torres Strait Islander Social Justice Commissioner's Native title report 2005 (Calma 2006). However, since that time several jurisdictions have made significant amendments to their legislation or introduced new legislation. As stated in the Native title report 2005, to ascertain particular details in the different jurisdictions, a closer analysis of the strengths, weaknesses and workability of the existing arrangements is required. 
The ability of title holders to deal in the land varies within and between jurisdictions. In most cases the land is inalienable and cannot be sold, transferred or otherwise dealt with, except in accordance with the provisions of the relevant legislation. Only in very few cases are there no statutory restrictions on dealings in the land.

Table 16.1 shows that in most cases land is not able to be sold on the open market, but in 20 instances a legislative basis already exists in all jurisdictions (with conditions attached) that enables leasehold interests to be created. In 15 instances this includes the ability to use the leasehold interest as security for a mortgage.

In response to the Commonwealth's and COAG's Aboriginal land tenure reform agenda of the last decade, only Queensland has enacted specific legislation that enables Aboriginal and Torres Strait Islander lands to be made freehold land and then traded in the open market. South Australia, by contrast, has recently endowed its existing Aboriginal Lands Trust with greater statutory independence and the ability to buy additional land on the open market and to undertake economic development on Trust land for the benefit of Aboriginal people. The Trust can also dispose of Trust land by transfer or grant of fee simple, but it can only do so if it is in accordance with a resolution of both Houses of Parliament and any requirements under the NTA have been satisfied.

From the perspectives of both economic engagement and social justice, perhaps the ideal situation is a 'no' in the sale column, and a 'yes' in the leasing and mortgaging columns. This would protect the underlying tenure of Aboriginal ownership, while also allowing use of the land as equity or security for finance. Fifteen of the 23 existing statutory land rights regimes show that this is possible. However, land rights land is also subject to native title rights and interests which, as discussed above and shown in the first row of Table 16.1, do not enable sale, lease or mortgage. 
16. DEALINGS IN NATIVE TITLE AND STATUTORY ABORIGINAL LAND RIGHTS LANDS

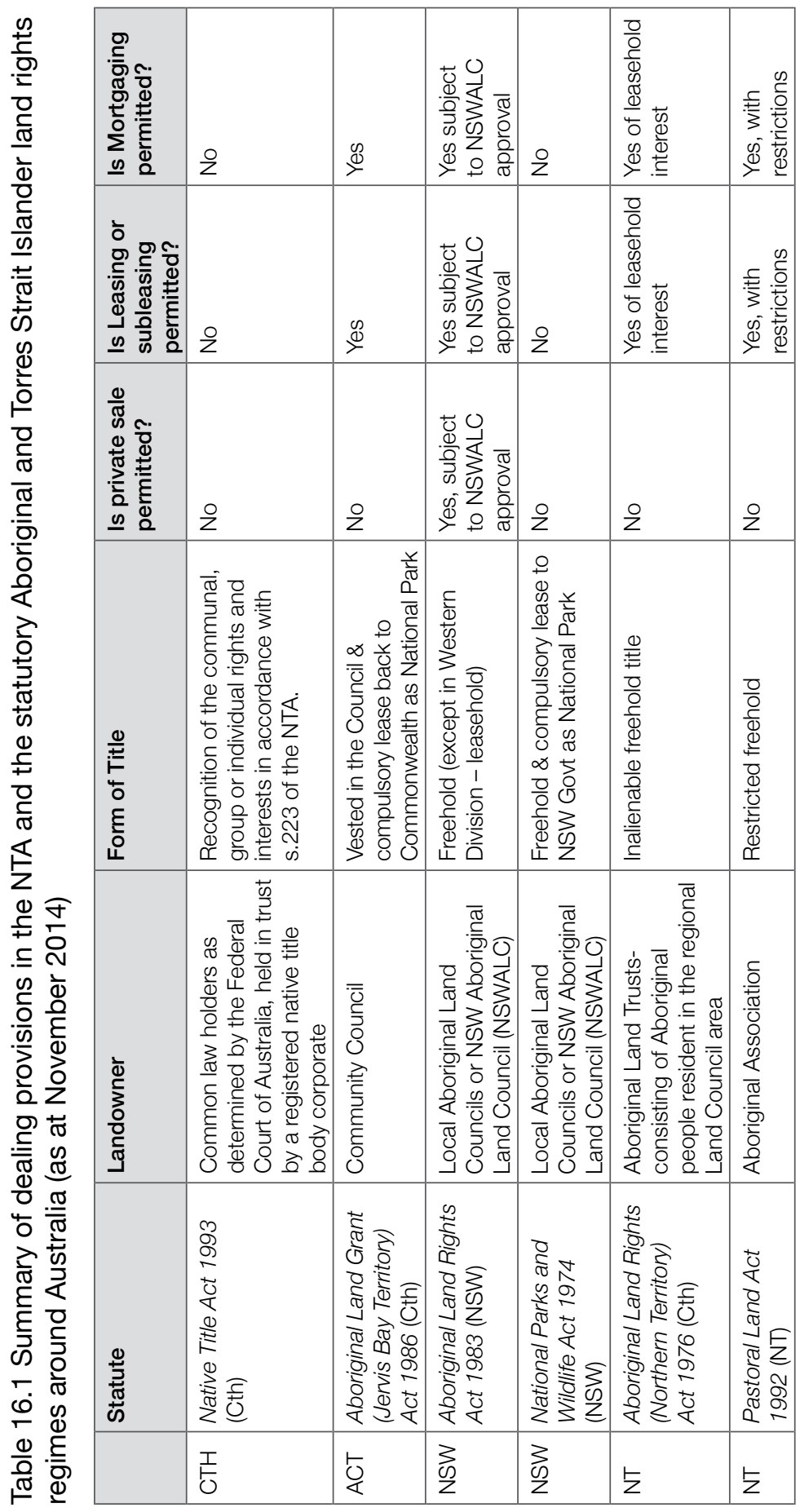


ENGAGING INDIGENOUS ECONOMY

\begin{tabular}{|c|c|c|c|c|c|c|c|c|c|c|}
\hline E & $\stackrel{\mathscr{D}}{>}^{\infty}$ & z & z & 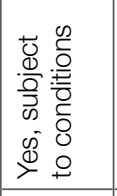 & $\stackrel{2}{2}$ & 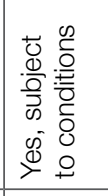 & z & z & 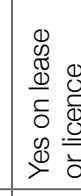 & $\stackrel{\infty}{>}$ \\
\hline 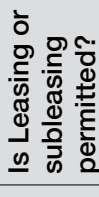 & ? & $\stackrel{\infty}{\nu}^{\infty}$ & 番 & $\stackrel{\infty}{-\infty}$ & 选 & 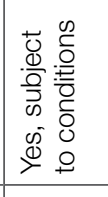 & 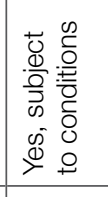 & 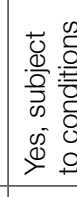 & $\stackrel{\mathscr{B}}{\nu}$ & 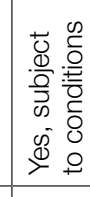 \\
\hline 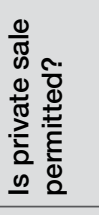 & 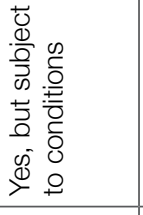 & 2 & z & 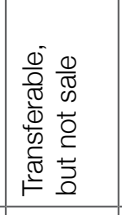 & 2 & 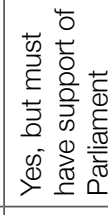 & ㅇ & 2 & z & z \\
\hline & $\begin{array}{l}\frac{0}{0} \\
\frac{\Phi}{0} \\
\text { L }\end{array}$ & 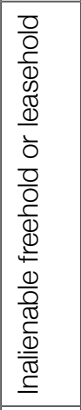 & 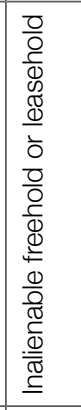 & 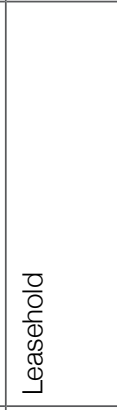 & 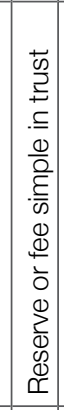 & 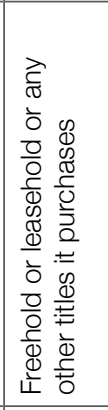 & 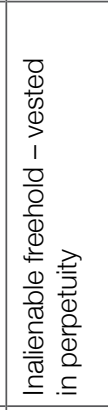 & 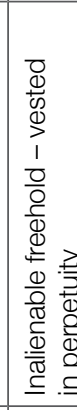 & 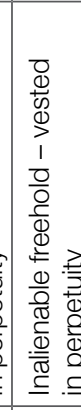 & 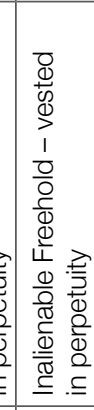 \\
\hline & 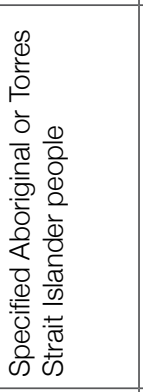 & 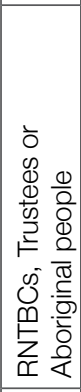 & 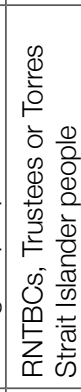 & 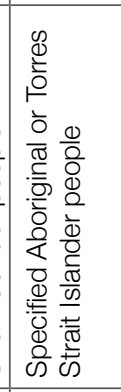 & & 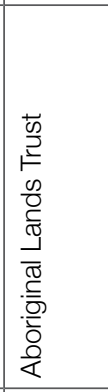 & 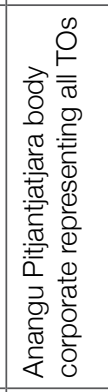 & 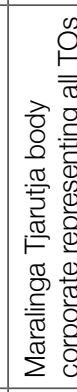 & 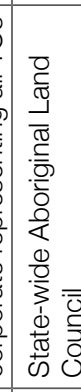 & 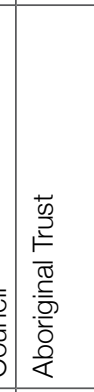 \\
\hline & 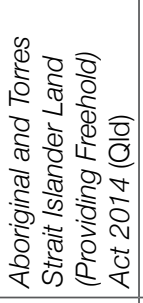 & 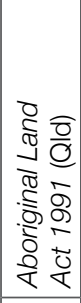 & 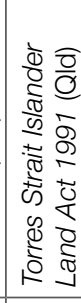 & 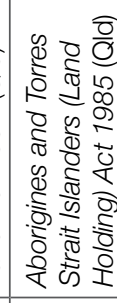 & & 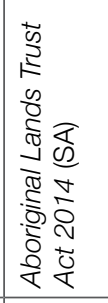 & 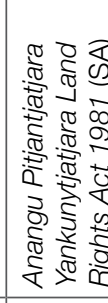 & 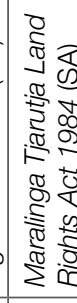 & 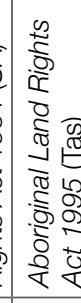 & 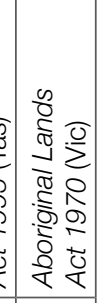 \\
\hline & वे & 0 & वे & वे & & & & की & $\stackrel{0}{\mathbb{E}}$ & \\
\hline
\end{tabular}


16. DEALINGS IN NATIVE TITLE AND STATUTORY ABORIGINAL LAND RIGHTS LANDS

\begin{tabular}{|c|c|c|c|c|c|c|c|}
\hline 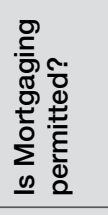 & 悉 & q & $\stackrel{\infty}{=}$ & क्ष & $\frac{0}{2}$ & 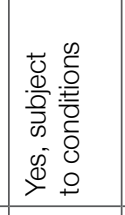 & 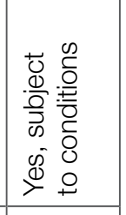 \\
\hline 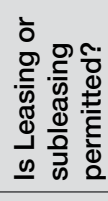 & 乐 & 2 & $\stackrel{\mathscr{S}}{=}$ & \& & 2 & 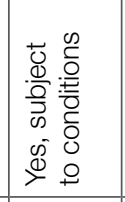 & 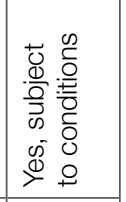 \\
\hline 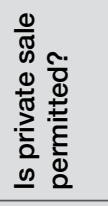 & 2 & z & 2 & z & 2 & z & 2 \\
\hline 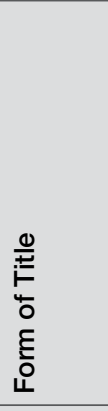 & 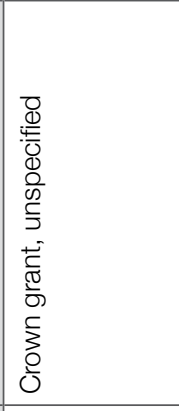 & 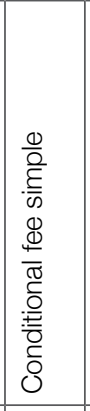 & 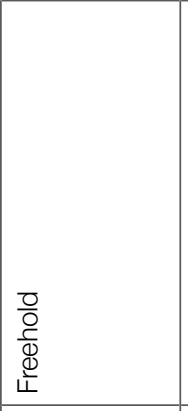 & 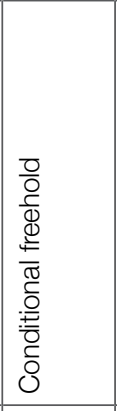 & 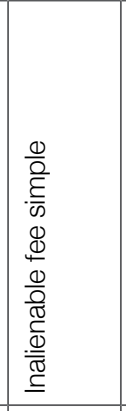 & 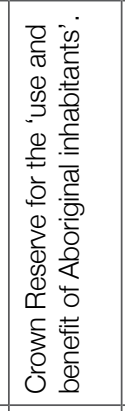 & 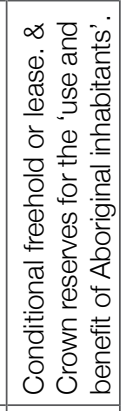 \\
\hline 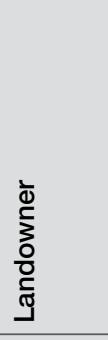 & 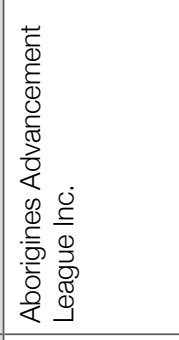 & 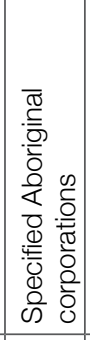 & 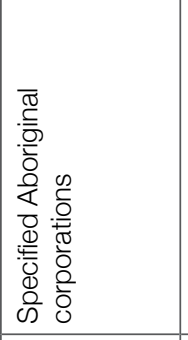 & 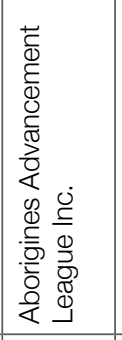 & 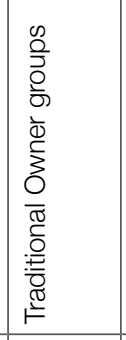 & 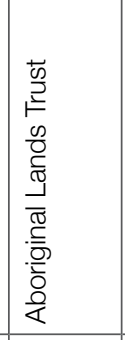 & 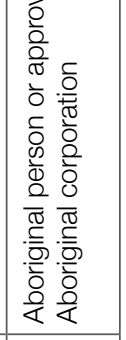 \\
\hline $\begin{array}{l}\text { 志 } \\
\text { 焉 }\end{array}$ & 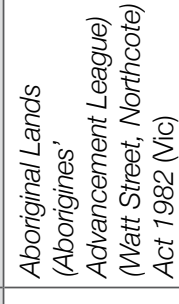 & 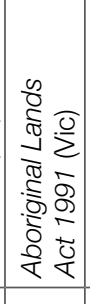 & 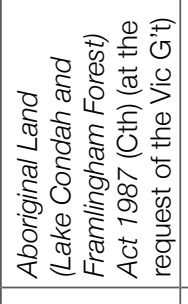 & 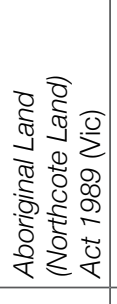 & 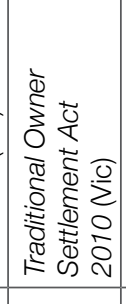 & 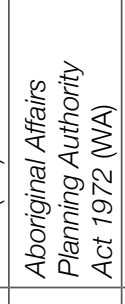 & 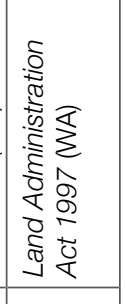 \\
\hline & $\frac{0}{5}$ & $\frac{0}{5}$ & $\frac{0}{5}$ & $\stackrel{0}{>}$ & $\stackrel{0}{>}$ & $\frac{1}{3}$ & $\$$ \\
\hline
\end{tabular}




\section{What land tenure reforms are needed?}

I have long stated that I believe there are two elements to Mabo (No. 2) (Wensing 1999). In substance, the judgement recognised that Eddie Mabo and others on behalf of the Meriam People of the Murray Islands in the Torres Strait had prior and continuing occupation and ownership of the Murray Islands. In essence, the judgement found that Aboriginal and Torres Strait Islander law and culture is recognised by the common law of Australia. As a consequence, there are now effectively two systems of land law in Australia, one deriving from colonisation, the other from prior traditional ownership of Australia by Aboriginal and Torres Strait Islander people. These conceptions flag some critical changes to the way we need to think about land tenure.

Aboriginal people have never ceded their lands and Australia has never dealt fairly with the Aboriginal and Torres Strait Islander people of Australia about the loss of their lands. We can no longer deny that at the root of all property in land for settler Australians were acts of dispossession of Aboriginal people, acts of theft for which no one has ever been held responsible (Kerruish \& Purdy 1998). This denial of the existence of prior Aboriginal ownership of Australia has become an international embarrassment. It is no longer tolerable that we continue constructing legal orthodoxies that suit the settler state. For example, the provisions in the NTA declaring that the extinguishment of native title has occurred (partly or wholly) will not make the laws and customs of Aboriginal and Torres Strait Islander people disappear.

As Robert French and Graeme Neate have both stated, the term 'extinguishment' is just a metaphor for placing limits upon the extent to which recognition will be accorded to Aboriginal and Torres Strait Islander peoples under Australian law (French $\mathrm{J}$ in The Lardil case 2001; Neate 2002: 118). Regardless of judicial or legislative status, Aboriginal and Torres Strait Islander people will always retain their special relationship with and responsibility for land and sea country (Rose 1996; Dodson 1998: 209).

Given the many constraints around native title, it is reasonable to ask whether native title holders are feeling somewhat frustrated or disillusioned because they are not able to use their property rights to engage in the modern economy on their terms when opportunities 
arise and without having to surrender and permanently extinguish their hard won native title rights and interests. Smith (2001:2) likens this to replacing 'the historical fiction of terra nullius with the legal fiction of extinguishment'. Little wonder that some commentators see native title as a 'dodgy conveyance' (Ring 2006).

It is time to 'puncture some legal orthodoxies' relating to property and land tenure (McHugh 2011). Let me finish with a few suggestions.

Real change has to happen inside the Crown's land tenure system. Let's turn the legal principles of property relations, inalienability and extinguishment on their proverbial heads. Let's develop a form of leasehold which will allow the native title holders to determine the terms and conditions for development on their lands so they can partake in the risks and benefits arising from land development and resource exploitation.

McAvoy (2014) believes that all Aboriginal and Torres Strait Islander people should aspire to ownership of their lands, planning control, self-determination, economic independence, and full compensation. My similar advice to native title holding groups is to make the most of any opportunity to reform state/territory land tenure systems, otherwise the opportunity will be lost for many decades and possibly generations to come. Use this opportunity to:

- make the most of being able to revive Aboriginal and Torres Strait Islander law and custom;

- take ownership of customary land in the strongest form of tenure possible;

- control uses of Aboriginal and Torres Strait Islander lands through planning regimes;

- be in control of your own future and destiny (self-determination);

- become economically independent; and

- seek full compensation for any loss, diminution or extinguishment of native title rights and interests.

Otherwise the essence of Aboriginal and Torres Strait Islander community life and culture will disappear. 
I hope, like Jon Altman, I have challenged you to think differently about these important issues relating to property, inalienability, extinguishment and non-extinguishment of customary Indigenous rights to land.

\section{References}

\section{Cases}

Mabo $v$ the State of Queensland [No. 2] (1992) 175 CLR1.

Pareroultja v Tickner (1993) 117 ALR 206.

The Lardil, Kaiadilt, Yangkaal and Gangalidda Peoples $v$ State of Queensland (2001) FCA 414.

\section{Reports and other documents}

Altman JC (2012). People on country as alternate development. In Altman JC \& Kerins S (eds), People on country, vital landscapes, Indigenous futures, The Federation Press, Sydney.

Altman JC (2014). The political ecology and political economy of the Indigenous titling 'revolution' in Australia. Maori Law Review March.

Calma T (2006). Native Title Report 2005, Australian Human Rights Commission, Sydney.

Dodson M (1998). Six years of native title: extinguishment of native title, public lecture at the University of New South Wales (UNSW), Native title: facts, fallacies and the future, University Symposium, Sydney, 30 May.

Edelmen D (2009). Native title settlements and the meaning of the term 'Traditional Owners', paper presented to the National Native Title Conference, Melbourne, 4 June.

Gover K (2012). A matter of trust: what we can learn from the Treaty of Waitangi. The Conversation 6 February. 
Kerruish V \& Purdy J (1998). He 'look' honest: Big White Thief. Law Text Culture 4:146-71.

McAvoy T (2014). An Assembly of First Nations and a Treaty, paper presented to the National Native Title Conference, Coffs Harbour, NSW, 4-5 June.

McHugh PG (2011). Aboriginal title: the modern jurisprudence of tribal land rights, Oxford University Press, Oxford.

Neate G (2002). Indigenous land rights and native title in Queensland: a decade in review. Griffith Law Review 11(1):90.

Ring G (2006). Native title and the seven-year itch. Online Opinion 21 September.

Rose DB (1996). Nourishing terrains: Australian Aboriginal views of landscape and wilderness, Australian Heritage Commission, Canberra.

SGS Economics and Planning (2012). Living on our lands, a study undertaken for the Department of Indigenous Affairs, unpublished, Government of Western Australia, Perth.

Smith D (2001). Valuing native title: Aboriginal, statutory and policy discourses about compensation, Discussion Paper 222, Centre for Aboriginal Economic Policy Research, The Australian National University, Canberra.

Wensing E (1999). Comparing native title and Anglo-Australian land law: two different timelines, two different cultures and two different laws, Discussion Paper 25, The Australia Institute, Canberra.

Wensing E (2013). Indigenous land tenure reforms: implications for land use planning, paper presented to the Planning Institute of Australia National Congress, Canberra, 25-27 March.

Wensing E \& Taylor J (2012). Secure tenure for home ownership and economic development on land subject to native title, Discussion Paper 31, Australian Institute of Aboriginal and Torres Strait Islander Studies, Canberra. 
This text is taken from Engaging Indigenous Economy: Debating diverse approaches, edited by Will Sanders, published 2016 by ANU Press, The Australian National University, Canberra, Australia. 